\title{
Environmental determinants of the at-sea distribution of encounters between flesh-footed shearwaters Puffinus carniepes and fishing vessels
}

\author{
Tim A. Reid ${ }^{1,2,3, *}$, Mark A. Hindell ${ }^{1}$, Chris Wilcox $^{2}$ \\ ${ }^{1}$ Institute of Marine and Antarctic Studies, Private Bag 129, University of Tasmania, Sandy Bay, Tasmania 7005, Australia \\ ${ }^{2}$ Wealth from Oceans National Flagship, CSIRO Marine and Atmospheric Research, GPO Box 1538, Hobart, Tasmania 7001, \\ Australia \\ ${ }^{3}$ Present address: Percy Fitzpatrick Institute of African Ornithology, Private Bag X3, University of Cape Town, \\ Rondebosch 7701, South Africa
}

\begin{abstract}
Fisheries observer data were used to model the distribution of seabird encounters in order to identify potential areas for fisheries closures. Data from the Australian Eastern Tuna and Billfish Fishery (ETBF) in the Tasman Sea were used, and the focal species was the flesh-footed shearwater Puffinus carneipes Gould, 1844 (the species most commonly killed in this fishery). Encounters between flesh-footed shearwaters and longline fishing vessels varied with season, distance from Lord Howe Island, and a number of environmental and oceanographic variables. Encounters were most common south-west of Lord Howe Island, in waters associated with the Tasman Front and the East Australian Current. The resulting model was used to predict overlaps between fisheries and flesh-footed shearwaters during 3 years (1997-98, 2003-04 and 2006-07). During 2003-04, high rates of interaction were predicted in areas with high fishing effort and high observed mortality rates of shearwaters. In 2006-07 most fishing was well to the north of areas with predictions of high interaction rates, and seabird bycatch was low. The shift in fishing locations coincided, and was likely driven by, a change in the fish species targeted by the majority of the fishery. This indicates that the most likely reason for falling bycatch rates in this fishery were movements of the fishing effort away from the birds, rather than changes in fishing technique. These results emphasise the potential of area closures as a method of bycatch mitigation for species that are proving intractable to standard bycatch reduction methods. Our results demonstrate that data collected from fisheries vessels can be used to identify characteristic areas of interactions.
\end{abstract}

KEY WORDS: Bootstrap model averaging · Long-line fishing $\cdot$ By-catch $\cdot$ Lord Howe Island · At-sea interactions

Resale or republication not permitted without written consent of the publisher

\section{INTRODUCTION}

Worldwide, many seabirds are killed in commercial fisheries operations, with some species being lost in sufficient numbers to adversely affect their conservation status. Particular attention has concentrated on albatrosses (e.g. Bartle 1991, Brothers 1991, Nel et al. 2002, Sullivan et al. 2006a, Anderson et al. 2011); however, a number of species of shearwaters and petrels are also severely affected (Brothers et al. 1999, Baker \& Wise 2005, Phillips et al. 2006, Thalmann et al. 2009). Thousands of flesh-footed shearwaters (Puffinus carneipes Gould, 1844) are estimated to have been killed during longline fishing in the Eastern Tuna and Billfish Fishery (ETBF) off the east coast of Australia (Baker \& Wise 2005, Tuck \& Wilcox 2010). The shearwaters killed in the fishery are thought to come primarily from the Lord Howe 
Island population, and a modeling study has suggested that the population cannot sustain the reported levels of mortality (Baker \& Wise 2005). This population has been shown to have been declining since the 1970s (Priddel et al. 2006).

A number of mitigation techniques have been used in fisheries to reduce this mortality, including nightsetting, rapidly sinking gear, and bird scaring lines; however, so far none have been found to be effective with flesh-footed shearwaters in the ETBF (Trebilco et al. 2010). Most methods of mitigation aim to reduce the impact of interactions once by-catch species encounter fishing vessels (Brothers et al. 1999, Sullivan et al. 2006b), and these methods can be less effective against deep diving or night foraging seabirds such as flesh-footed shearwaters and whitechinned petrels (Brothers et al. 1999).

An alternative strategy may be to reduce mortalities by decreasing the number of seabirds that encounter fishing vessels in the first place, for example by preventing fishing in areas that have high numbers of seabirds. Seabird by-catch increases with abundance of seabirds around fishing vessels, so avoiding areas with high concentrations of frequently caught species of birds may provide a simple and effective measure (Trebilco et al. 2010). However, to adopt this strategy, we need to improve our understanding of the at-sea distribution of seabirds, such as flesh-footed shearwaters, and the underlying factors that determine it.

Broadly speaking, there are 2 ways to quantify the distribution of seabirds: via telemetry (Shaffer et al. 2006), or using observations of seabirds at sea (Reid et al. 2002, Camphuysen et al. 2004). Data loggers and satellite tracking devices provide detailed information, but generally only on a small numbers of individuals. The weight of the devices also limits the size of birds that can be studied in this way, although with devices becoming ever smaller, the number of species that can be studied is steadily increasing. The alternative, data from at-sea observations, has the advantage of being derived from larger number of birds. However, collection of at-sea observations may be expensive. Another alternative is to use counts of attending seabirds that are frequently made during fisheries operations for fisheries management purposes, but these data have rarely been used for looking at the distribution of the seabirds at sea, as the data are considered to be biased because some species of seabirds (e.g. albatross) are attracted to vessels, while others may avoid them (Hyrenbach 2001). Additionally, fisheries observers generally have a number of other activities to perform relating to fish- eries management, and so they do not have time to use distance or area sampling techniques (Spear et al. 2004). However, if the data for a single species are used to answer well-targeted questions, these issues are likely to be lessened. For instance, if a species is attracted to fishing vessels, counts of that species can appropriately be used for quantifying their relative distribution, and the likelihood of interaction with vessels.

Seabirds, such as flesh-footed shearwaters, forage over the ocean in a targeted, rather than a random, manner (Pinaud \& Weimerskirch 2005, Thalmann et al. 2009). Their at-sea distribution is restricted due to the constraints of central place foraging during the breeding season (Orians \& Pearson 1979, Kacelnik 1984). They are likely to forage in areas where they will increase their chances of encountering food (Barraquand \& Benhamou 2008), such as regions of mixing associated with fronts between currents, and upwellings of nutrient-rich bottom water in the vicinity of land and benthic features (Schneider 1982, Reid \& Hindell 2000). However, these areas may not be easy to locate (either for fishers or the birds), and it may not be possible to measure the presence of prey directly. Therefore, if we can identify environmental descriptors that are correlated with the seabirds' or their prey's distribution, it may be possible to model the areas that are liable to have increased encounter rates between the seabird and fisheries. These could then be used to make forecasts of areas of high encounter rates, facilitating the use of avoidance as an alternative method for reducing bycatch in some species of seabirds.

In this study we used data collected from fishing vessels in the ETBF to examine the distribution of flesh-footed shearwaters in the Tasman Sea in relation to fishing vessels. From these data we aimed to develop models to describe the environmental characteristics in the areas of interactions, to predict areas where interactions between fisheries and shearwaters are most likely to occur, to identify areas likely to have increased seabird mortality, and discuss the management of fisheries in relation to seabird mortality and the potential use of area closures.

\section{MATERIALS AND METHODS}

The flesh-footed shearwater is a medium sized procellariiform. These birds are trans-equatorial migrants, breeding off the North Island of New Zealand (25000 to 50000 breeding pairs), at Lord Howe Island (17000 pairs), off the south coast of 
Western Australia (100000 to 200000 pairs) and on Ile St Paul in the southern Indian Ocean (600 pairs; Marchant \& Higgins 1990, Ross et al. 1996, Priddel et al. 2006). They breed during the austral summer, with egg-laying occurring in late November, hatching in late January and chick departure in late April or early May. During the austral winter, they migrate to either the North Pacific or the north Indian Ocean (Marchant \& Higgins 1990). During the breeding season, flesh-footed shearwaters from Lord Howe Island forage between $22-42^{\circ} \mathrm{S}, 150-166^{\circ} \mathrm{E}$, moving south as summer progresses (Fig. 1; Thalmann et al. 2009, authors' unpubl. data). Significant bycatch of flesh-footed shearwaters has been recorded in longline fisheries off the east coast of Australia, with most occurring during summer and south of $30^{\circ} \mathrm{S}$ (Baker \& Wise 2005, Trebilco et al. 2010)

Lord Howe Island is a 1455 ha volcanic island situated in the Tasman Sea at $31^{\circ} 30^{\prime} \mathrm{S}, 159^{\circ} 05^{\prime} \mathrm{E}, 495 \mathrm{~km}$ east of Australia (Priddel et al. 2006). It is located on the western side of a significant bathymetric feature: the Lord Howe Rise. There are a number of other important oceanographic features in the Tasman Sea, in particular, the western boundary current running down the east coast of Australia (the East Australia Current, EAC), which transports warmer tropical waters into the Southern Ocean. The EAC consists of a series of anti-cyclonic eddies of $\sim 250 \mathrm{~km}$ diameter moving south along the east coast of Australia (Stanton 1981). They are strongest during the austral summer, moving south as far as Tasmania (Stramma et al. 1995). Midway down the north New

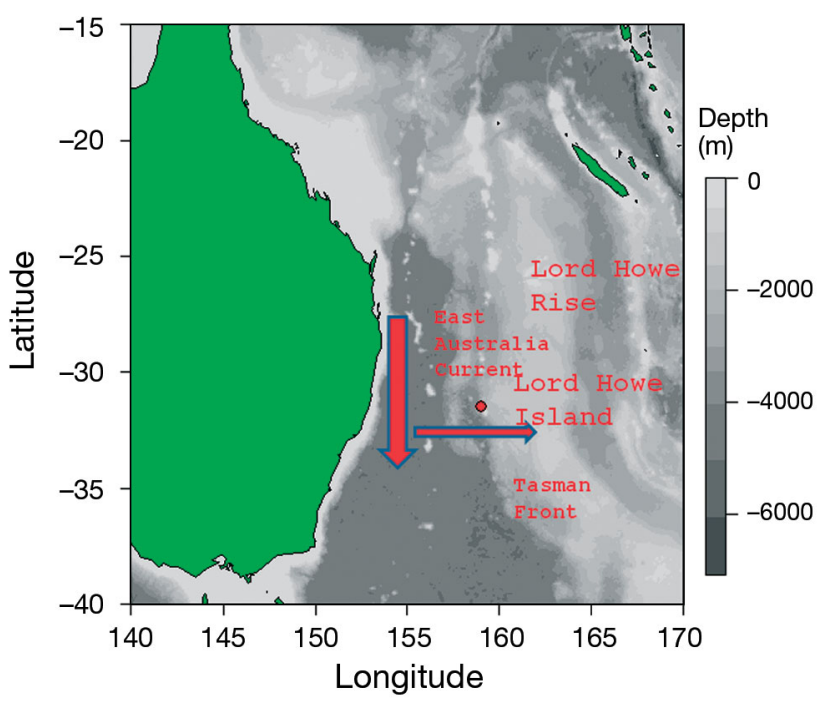

Fig. 1. Australia and Tasman Sea, with Lord Howe Island (๑), Lord Howe Rise, and approximate locations of the East Australian Current(EAC) and Tasman Front (TF)
South Wales coast (approximately off Coffs Harbour), the EAC splits, with most water flowing eastwards to the north island of New Zealand (Stramma et al. 1995). This flow is known as the Tasman Front, and it passes close to Lord Howe Island (to the south in summer and north in winter).

The ETBF operates off the east coast of Australia, from Cape York, to the Victorian/South Australian border, and includes waters around Norfolk Island and Tasmania. The main fishing technique used is long-lining, and the main target species are yellowfin tuna Thunnus albacares Bonnaterre, 1788, bigeye tuna T. obesus Lowe, 1839, albacore tuna T. alalunga Bonnaterre, 1788, broadbill swordfish Xiphias gladius Linnaeus, 1758 and striped marlin Tetrapturus audax Philippi, 1887. In March 2008 there were 55 active long-line licenses for this fishery with a total catch of 6,399 t (\$A 38.9 million) (AFMA 2011). The Australian Fisheries Management Authority (AFMA) retains the right to close down this fishery if too much mortality of threatened species occur (AFMA 2008). This occurred due to albatross bycatch in August 2008 (AFMA 2008).

\section{Data sources}

AFMA requires long-line vessels operating within Australian waters to carry observers on some voyages. These observers record the number of seabirds observed within $300 \mathrm{~m}$ of the vessel for a 2 to $3 \mathrm{~min}$ period during line setting. AFMA observers provide $\sim 3 \%$ coverage of the total fishing effort in the fishery (Trebilco et al. 2010). Vessels also record their fishing position and their daily catch for all operations, and these data are supplied to AFMA. Vessels in this fishery usually set one line per day.

Data for environmental parameters were obtained from a number of sources using the SDODE software (Table 1) (Hobday et al. 2006). Environmental data were obtained for each fishing location (Hobday et al. 2006).

\section{Data analysis}

We modeled the counts of flesh-footed shearwaters with generalized linear models (GLM), using the counts as the response variable, and environmental data as descriptors. Because the seabird data are counts, we initially considered that a Poisson error distribution would be appropriate. However, the data were strongly over-dispersed (variance was consid- 
Table 1. Variables tested in a generalized linear model (GLM). AltAnom: sea height anomaly, Bathy: bathymetry, SST: sea surface temperature, Breed: breeding stage (Prospecting: Sep-Oct; Egg: Dec-Jan; Early chick rearing: Feb; Late chick rearing: Mar-Apr; Winter: May-Aug)

\begin{tabular}{|c|c|c|c|c|c|}
\hline $\begin{array}{l}\text { Variable } \\
\text { name }\end{array}$ & $\begin{array}{l}\text { Categorical/ } \\
\text { continuous }\end{array}$ & Values & Range & Data source & Data accuracy \\
\hline Breed & Categorical & $\begin{array}{l}\text { Early chick rearing, } \\
\text { Egg, Late chick rearing, } \\
\text { Prospecting, Winter }\end{array}$ & & & \\
\hline Distance & Continuous & Km from Lord Howe Island & $69-2289$ & & \\
\hline Altimetry & Continuous & Mean sea height $(\mathrm{m})$ & $-0.08-0.17$ & $\begin{array}{l}\text { MSLA (Maps of Sea Level Anomaly) } \\
\text { derived from the satellites TOPEX/ } \\
\text { POSEIDON and ERS-1 }\end{array}$ & $0.193 \times 0.333^{\circ}$ \\
\hline AltAnom & Continuous & $\begin{array}{l}\text { Variation in sea height } \\
\text { from mean }(\mathrm{m})\end{array}$ & $-0.27-0.24$ & $\begin{array}{l}\text { synTS CSIRO product } \\
\text { (www.marine.csiro.au/dods-data/ } \\
\text { bluelink/synTS/) produced and } \\
\text { maintained by M. Cahill }\end{array}$ & $0.25 \times 0.25^{\circ}$ \\
\hline Bathy & Continuous & Depth (m) & $-2-(-5240)$ & $\begin{array}{l}\text { Gridded Global Relief Data from US } \\
\text { Department of Commerce, National } \\
\text { Oceanic and Atmospheric Administration } \\
\text { (NOAA), National Geophysical Data } \\
\text { Center, 2006 (www.ngdc.noaa.gov/ } \\
\text { mgg/fliers/06mgg01.html) }\end{array}$ & $0.0333 \times 0.0333^{\circ}$ \\
\hline Chl a & Continuous & Ocean productivity $\left(\mathrm{mg} \mathrm{m}^{-3}\right)$ & $0.05-0.58$ & http://seawifs.gsfc.nasa.gov/SEAWIFS & $0.0833 \times 0.0833^{\circ}$ \\
\hline Front & Continuous & $\begin{array}{l}\text { Concentration of oceano- } \\
\text { graphic fronts }\end{array}$ & $0-3.59$ & $\begin{array}{l}\text { CSIRO (J. Hartog \& A. Hobday unpubl. } \\
\text { data) every } 7.94 \text { d }\end{array}$ & $0.25 \times 0.25^{\circ}$ \\
\hline SST & Continuous & $\left({ }^{\circ} \mathrm{C}\right)$ & $14.17-29.44$ & CSIRO 6 d composite & $0.036 \times 0.042^{\circ}$ \\
\hline $\mathrm{U}_{\text {wind }}$ & Continuous & $\begin{array}{l}\text { Longitudinal component } \\
\text { of wind speed }\left(\mathrm{m} \mathrm{s}^{-1}\right)\end{array}$ & $-7.89-6.16$ & $\begin{array}{l}\text { Monthly data from NCEP Reanalysis } \\
\text { data provided by the NOAA-CIRES } \\
\text { Climate Diagnostics Center, Boulder, } \\
\text { Colorado (www.cdc.noaa.gov) }\end{array}$ & $2.5 \times 2.5^{\circ}$ \\
\hline $\mathrm{V}_{\text {wind }}$ & Continuous & $\begin{array}{l}\text { Latitudinal component } \\
\text { of wind speed }\left(\mathrm{m} \mathrm{s}^{-1}\right)\end{array}$ & $-3.07-8.58$ & $\begin{array}{l}\text { Monthly data from NCEP Reanalysis } \\
\text { data (NOAA-CIRES Climate Diagnostics } \\
\text { Center, Boulder, Colorado) }\end{array}$ & $2.5 \times 2.5^{\circ}$ \\
\hline Wind & Continuous & Wind speed $\left(\mathrm{m} \mathrm{s}^{-1}\right)$ & $4.24-9.46$ & $\begin{array}{l}\text { Monthly data from NCEP Reanalysis } \\
\text { data (NOAA-CIRES Climate Diagnostics } \\
\text { Center, Boulder, Colorado) }\end{array}$ & $2.5 \times 2.5^{\circ}$ \\
\hline
\end{tabular}

erably greater than the mean), so we used a zeroinflated model. Models resulting from these zeroinflated methods have 2 parts to them (and hence, 2 related models): one group of explanatory variables for the excess zeros in the data (the binomial model, modeling the chance of birds being observed), and a second group (which may include the same explanatory variables) for the counts in the data (modeling the numbers present on those shots, i.e. lines set, for which there is a chance birds are present). The zeroinflation part of the model can be considered equivalent to performing a binomial (presence/absence) test of the data. We explored a number of distributions to model the count component, including lognormal (e.g. Pennington 1996), Poisson (e.g. Lambert 1992) and negative binomial (e.g. Minami et al. 2007). Initial testing indicated a zero-inflated negative binomial (ZINB) model gave the best fit for this data. We used the pscl package v1.03 (Zeileis et al. 2007) in the R statistical package v2.6.1 (R Development Core Team 2007).

Up to 14 counts were made within single cruises, resulting in the potential for auto-correlation within a cruise (counts may not be truly independent due to the possibility of birds following between counts). Therefore, auto-correlation was tested for using a correlogram of differences of shearwater counts during long-line setting at different time lags within a fishing trip (successively comparing each count in a fishing trip to the next one) using methods from Cressie (1993).

Testing showed there was autocorrelation in the data, and so a bootstrap method was used for model building. To deal with issues of model uncertainty, a 2-step bootstrap model averaging approach was used (Buchholz et al. 2007). The first step in this process 
is designed to eliminate those variables that have negligible effect on the outcome (Buchholz et al. 2007). To do this, a single observation (from a set) was randomly chosen from each cruise. A stepwise process was then used to identify the explanatory variables giving the best fit for the response variable (using Akaike information criterion [AIC] in the step.zic function from the zic package v1.0 of the R statistical program) (R Development Core Team 2007). This was then repeated 200 times, each time randomly selecting a single observation from each cruise. From these 200 models, only those explanatory variables that appeared in at least $20 \%$ of models were used $(20 \%$ as chosen by Buchholz et al. 2007).

The second stage was a model averaging step, where the variables kept in the first step were used to run a further stepwise process 250 times (Buchholz et al. 2007). The models that occurred most frequently in the 250 iterations (appearing in $>50 \%$ of models) were then used as the final models to predict the number of shearwaters. Responses were predicted by a weighted average of predictions from the 250 models, with the frequency of a model appearing acting as a weighting factor. Variance in the model was calculated using methods from Buckland et al. (1997) and Buchholz et al. (2007).

We validated the final model in 2 steps: The first was using the final model to predict the counts of a sub-sample of observations with observed counts that were not used in model development, using the predict function in R. From these, the correlation between observed and predicted counts was compared. We then examined the residuals from the model for spatial or temporal patterns that might indicate missing covariates.

After validation, we used these models to make predictions of seabird encounters by the $97 \%$ of the fishing effort that was not directly observed. We applied it to $3 \mathrm{yr}$ of fisheries data taken from fishing vessels in which observers were not present: 199798, 2003-04 and 2006-07. These years were chosen as years when the fishery generally targeted swordfish (1997-98), yellowfin (2003-04), and albacore (200607) (N. Dowling CSIRO Marine pers. comm.). AFMA logbook data for each year from July to June were used for making predictions of encounter rates. The predict function in the R statistical program was then used to predict counts, which were then used with effort data to model the distribution of encounters between fishing vessels and flesh-footed shearwaters during the 12 mo period. Effort data was plotted after being smoothed using the interp function with bilinear interpolation from the akima package v0.5.1 in R.
Table 2. Mean $( \pm \mathrm{SD})$ counts of observed flesh-footed shearwaters during different seasons of the year. Prospecting: Sep-Oct; Egg: Dec-Jan; Early chick rearing: Feb; Late chick rearing: Mar-Apr; Winter: May-Aug

\begin{tabular}{|lrl|}
\hline & N & Mean $( \pm$ SD $)$ \\
\hline Prospecting & 340 & $60.3( \pm 201.8)$ \\
Egg & 211 & $25.1( \pm 76.4)$ \\
Early chick & 181 & $74.8( \pm 139.2)$ \\
Late chick & 381 & $48.0( \pm 94.1)$ \\
Winter & 1004 & $1.9( \pm 18.0)$ \\
\hline
\end{tabular}

Table 3. Mean $( \pm \mathrm{SD})$ counts of observed flesh-footed shearwaters for different species targeted by fishing vessels. ALB: albacore; BET: bigeye tuna; OTH: other species; SBF: southern bluefin tuna; SWO: broadbill swordfish; YFT: yellowfin tuna

\begin{tabular}{|lrc|}
\hline & N & Mean $( \pm$ SD) \\
\hline ALB & 35 & $0.9( \pm 2.1)$ \\
BET & 298 & $10.2( \pm 40.0)$ \\
OTH & 129 & $10.2( \pm 41.5)$ \\
SBF & 133 & $0.2( \pm 1.8)$ \\
SWO & 259 & $63.7( \pm 222.3)$ \\
YFT & 1263 & $30.6( \pm 87.9)$ \\
\hline
\end{tabular}

\section{RESULTS}

A total of 2148 counts were made of flesh-footed shearwaters on 864 cruises within the ETBF between 27 September 2001 and 8 July 2006, with a mean of $26.2 \pm 85.6$ flesh-footed shearwaters per count. The individual counts ranged from 0 to 825 birds, and $1514(70 \%)$ of all counts had no observed shearwaters.

Flesh-footed shearwaters sightings were most common during the Prospecting and Early chick period (Table 2), and when vessels were targeting broadbill swordfish or yellowfin tuna (Table 3). They were seen in greater numbers closer to Lord Howe Island and in waters of shallower depth. Most sightings were south of $25^{\circ} \mathrm{S}(92 \%$ of sightings and $99 \%$ of total flesh-footed shearwaters counted).

\section{Modelling shearwater counts}

For the first step of the 2-step bootstrap, 5 variables (distance, breed, wind, altimetry and chl a) occurred in at least $20 \%$ of the count models, while 6 variables (distance, breed, chl a, altimetry, AltAnom [altimetry anomaly] and Bathy [bathymetry]) occurred in at least $20 \%$ of the zero-inflation (presence/absence) 
Table 4. Variable frequency in the first step of bootstep modeling, both in the negative binomial (counts; i.e. variables increasing the observed counts) and the binomial (zero inflation; i.e. variables affecting whether birds are present) part of the model. See Table 1 for definitions

\begin{tabular}{|c|c|c|c|}
\hline & Variable & $\mathrm{n}$ & $\begin{array}{c}\% \text { of models } \\
\text { containing variable }\end{array}$ \\
\hline \multirow[t]{11}{*}{ Counts } & Distance & 160 & 100.00 \\
\hline & Breed & 160 & 100.00 \\
\hline & Wind & 128 & 80.00 \\
\hline & Altimetry & 91 & 56.88 \\
\hline & Chl a & 56 & 35.00 \\
\hline & $\mathrm{V}_{\text {wind }}$ & 15 & 9.38 \\
\hline & $\mathrm{SST}$ & 18 & 11.25 \\
\hline & Bathy & 0 & 0.00 \\
\hline & Front & 8 & 5.00 \\
\hline & AltAnom & 14 & 8.75 \\
\hline & $\mathrm{U}_{\text {wind }}$ & 2 & 1.25 \\
\hline \multirow{11}{*}{$\begin{array}{l}\text { Zero } \\
\text { inflation }\end{array}$} & Distance & 160 & 100.00 \\
\hline & Breed & 160 & 100.00 \\
\hline & Wind & 3 & 1.88 \\
\hline & Altimetry & 80 & 50.00 \\
\hline & Chl a & 134 & 83.75 \\
\hline & $\mathrm{V}_{\text {wind }}$ & 12 & 7.50 \\
\hline & $\mathrm{SST}$ & 6 & 3.75 \\
\hline & Bathy & 32 & 20.00 \\
\hline & Front & 26 & 16.25 \\
\hline & AltAnom & 47 & 29.38 \\
\hline & $\mathrm{U}_{\text {wind }}$ & 24 & 15.00 \\
\hline
\end{tabular}

models (Table 4). All of these variables occurred in at least one of the best models developed in the second step of the process, and so were used in the final model (Table 5). Coefficients for variables used in the final model only changed slightly between models (Table 5). Breed, distance, chl a and sea height occurred in the zero inflated and the count model, AltAnom and Bathy occurred in the zero inflation model, and wind occurred in the count model. Fleshfooted shearwaters were significantly more abundant around fishing boats in Early chick period, closer to Lord Howe Island, at lower wind speeds, with high chl a concentrations, decreasing sea depth, decreasing sea height and with increasing sea height anomaly (Table 5).

\section{Model validation}

When the final model was used to compare predicted shearwater counts for the data set with observer counts (Fig. 2), there was a correlation coefficient of 0.58 (an adjusted R-squared value of 0.33 ). The predicted counts showed a large proportion of the data being a zero, reflecting the pattern in the

Table 5. The 10 most frequently occurring models (142 of 250 model runs) in the second step of the bootstep averaging approach. N: number of times the model occurred; Percent: \% of 142. Coefficients in the count model = counts (i.e. positive coefficient $=$ increasing count); coefficients in zero inflation model $=$ proportion of zero counts (i.e. positive coefficient $=$ increasing proportion of zero counts). Mean and SD calculated using methods from Buckland et al. (1997) and Buchholz et al. (2007). AIC: Akaike information criterion function. Prospecting: Sep-Oct; Egg: Dec-Jan; Late chick rearing: Mar-Apr;

Winter: May-Aug. See Table 1 for definitions

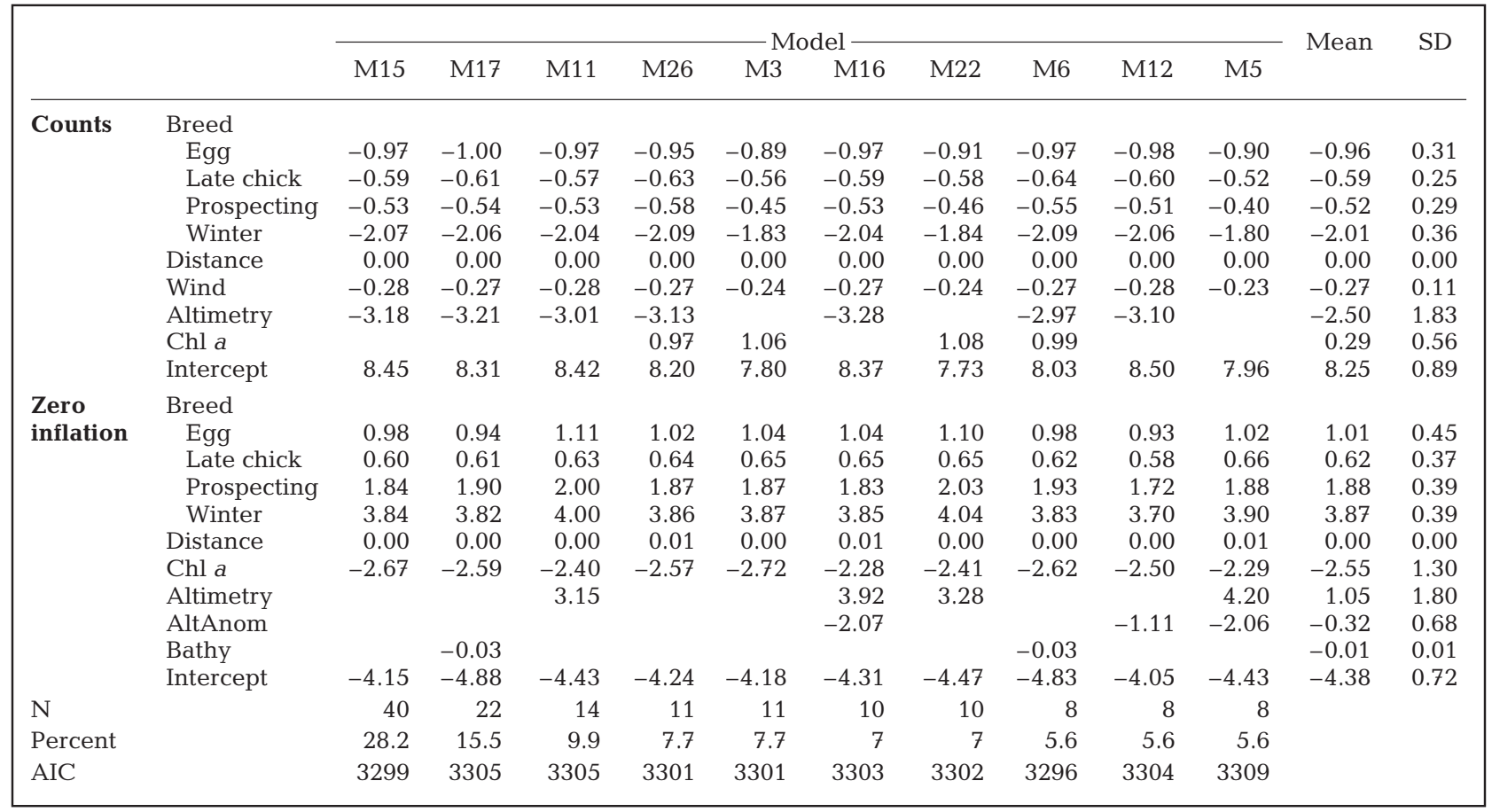




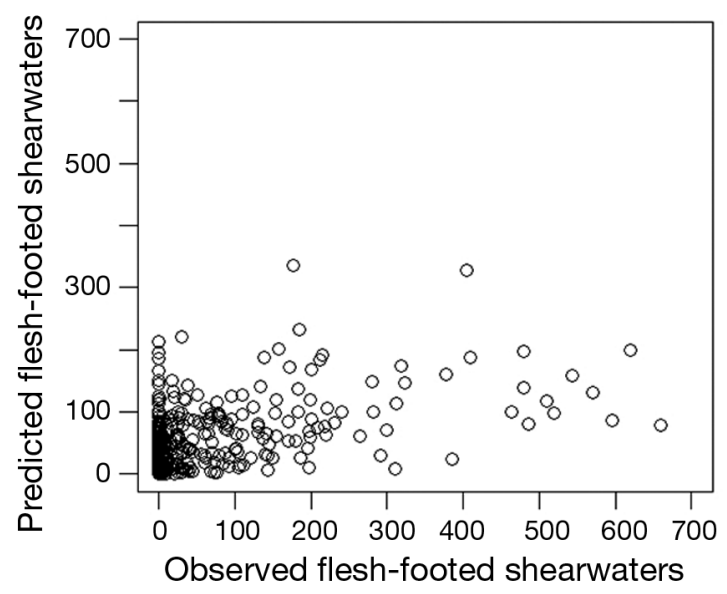

Fig. 2. Observed and predicted counts of flesh-footed shearwaters

observed data (Fig. 2). The predicted counts were similar to the observed counts at lower values, but higher counts were underestimated (Fig. 2). In addition, there were less zero counts in the predicted data than in the observed data, indicating that the observed data is still somewhat over dispersed relative to the predicted data.

The season that showed the greatest difference between observed and predicted counts was the Prospecting period, while winter had the least. Areas with the greatest mean deviation were around Lord Howe Island, and between Lord Howe Island and mainland Australia. Most of the larger counts (>200 flesh-footed shearwaters) were near mainland Australia between 30 and $33^{\circ} \mathrm{S}$ in 2001 and 2002 .

\section{Predicting encounters from unobserved fishing events}

Predicted encounters between flesh-footed shearwaters and fishing vessels, and fishing effort during 3 years (1997-98, 2003-04 and 2006-07) were plotted (Fig. 3). For all 3 years, the model predicts that highest encounters with fishing vessels will occur around Lord Howe Island and to the south-west in the area around the Tasman Front, with other areas of con- centration within the EAC (Fig. 3a,c,e). In comparison, the distribution of fishing effort changed greatly between years. The greatest encounters between shearwaters and long-liners were expected in 200304 (Table 6). In 1997-98 effort was concentrated close to the coast of Australia near the EAC and to the north-west of Lord Howe Island in the area of $25^{\circ} \mathrm{S}$, $155^{\circ} \mathrm{E}$ off Mooloolaba (Fig. 3b). In comparison, in 2003-04 there was effort concentrated between Lord Howe Island and Australia, but also to areas to the east of Lord Howe Island (Fig. 3d). In 2006-07 effort was concentrated to the north of $30^{\circ} \mathrm{S}$ and west of $155^{\circ} \mathrm{E}$ (Fig. 3f), with $39 \%$ of shots north of $25^{\circ} \mathrm{S}$ (Table 6), and relatively clear of areas of greatest encounters with flesh-footed shearwaters (Fig. 3e).

\section{DISCUSSION}

The data used in our study were collected by fisheries observers and have a number of inherent problems, such as the attraction of fishing vessels for birds (especially once the first bird has arrived) and the tendency of birds to remain with a vessel once they have located it. The most useful approach is using a model, such as adopted here, and judging if the result appears reasonable, while recognizing the limitations of the data. Because of this, our model should be considered as encounters between the seabirds and fishing vessels rather than being of their 'normal' distribution (though, these may be the same).

The modeling approach adopted here follows a GLM-based method. While it generally predicted the data reasonably well, it was not so good at dealing with large counts. In order to better deal with this, it is likely that a radically different approach may be necessary.

While all predators should go to areas of relatively high food availability, these areas may not be the same for each species, as they will each perceive the environment differently and may have different food requirements. For example, central place foragers are required to return to their nest and are thus restricted to within a certain range of their breeding

Table 6. Summary of effort and predictions of mean $( \pm \mathrm{SD})$ encounters between flesh-footed shearwaters and longline fishing boats in $3 \mathrm{yr}$, with percentage of shots made north of $25^{\circ} \mathrm{S}$. Mean latitude and longitude = mean fishing position

\begin{tabular}{|lcccrr|}
\hline Year & Shearwaters & Mean latitude & Mean longitude & \% north of 25 $\mathrm{S}$ & Total shots \\
\hline $1997-98$ & $22.66+37.95$ & $-28.06 \pm 7.33$ & $152.38 \pm 3.51$ & 26.12 & 9765 \\
$2003-04$ & $37.08 \pm 60.61$ & $-27.44 \pm 5.91$ & $154.68 \pm 4.62$ & 22.11 & 11755 \\
$2006-07$ & $22.58 \pm 48.97$ & $-25.21 \pm 5.81$ & $154.03 \pm 3.52$ & 38.94 & 7289 \\
\hline
\end{tabular}



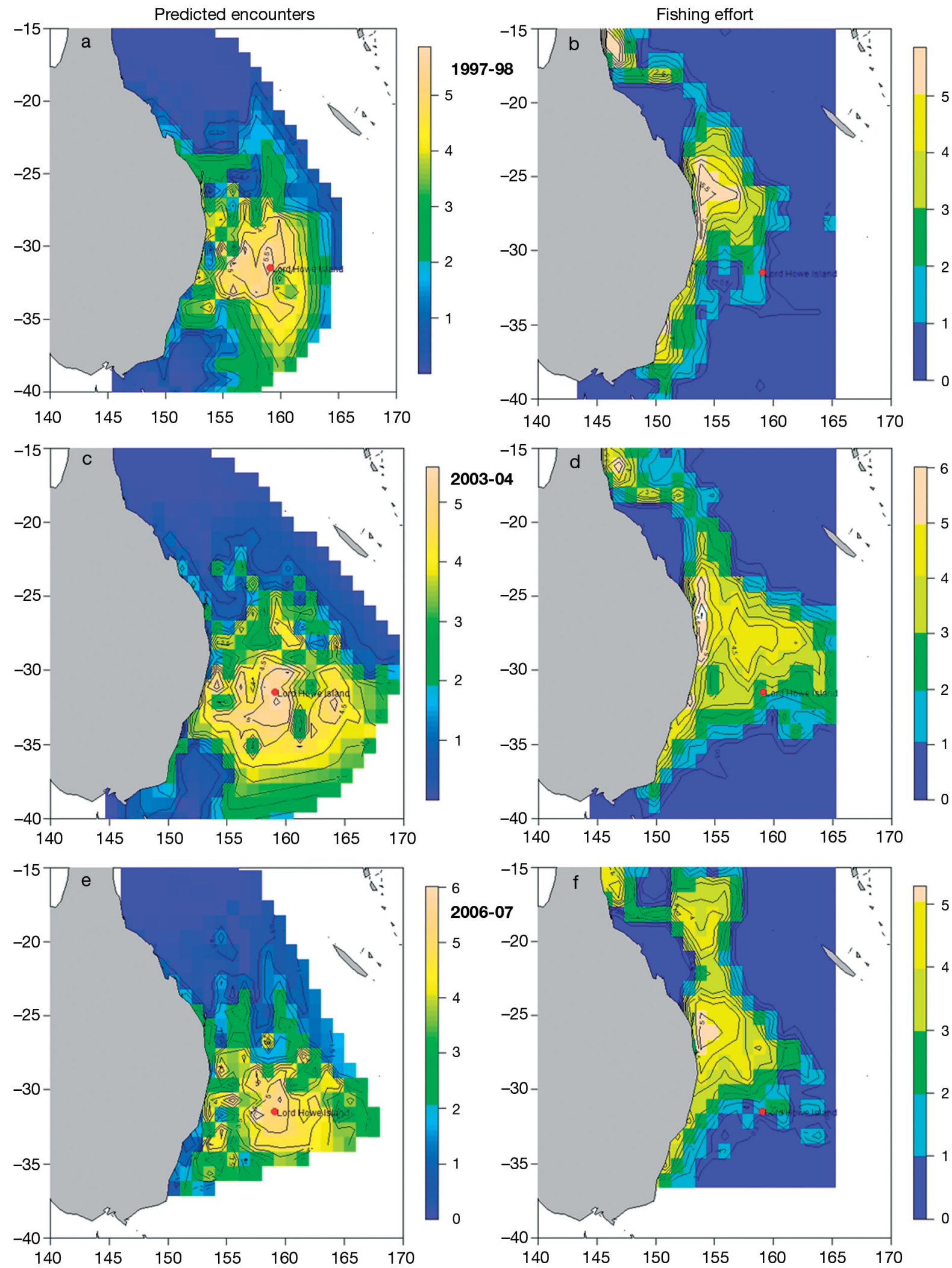

Fig. 3. (a,c,e) Predicted encounters of fishing vessels with flesh-footed shearwaters and (b,d,f) distribution of fishing effort in Eastern Tuna and Billfish Fishery (ETBF) in (a,b) 1997-98, (c,d) 2003-04 and (e,f) 2006-07. Fishing effort is the count for each $1^{\circ}$ block $\log$ transformed 
site (Orians \& Pearson 1979, Kacelnik 1984). Fishing vessels operating in this fishery are also central place foragers. Fish such as tuna, on the other hand, have different constraints, not being required to return at regular intervals for nesting. Therefore, although they have similar prey, their distribution may only partially overlap (Bestley et al. 2008).

\section{Understanding factors driving encounters}

The distribution of flesh-footed shearwaters was best described by the time of year and distance from Lord Howe Island. They were seen in greatest numbers during chick-rearing and prospecting periods, and least during incubation and especially in winter. Numbers were also inversely proportional to the distance from Lord Howe Island, with no birds observed $>1000 \mathrm{~km}$ away. These are broadly the expected results of the seasonal distribution of a migratory central-place forager.

In addition to the broader determinants of distribution, a number of environmental and oceanographic variables were also important in the models. Fleshfooted shearwaters were more commonly encountered by fishing vessels around the shelf edges or sea mounts, rather than the open ocean. This is similar to at sea observations and tagging results for the distribution of the flesh-footed shearwaters in the Tasman Sea (Reid et al. 2002, Thalmann et al. 2009). They were also seen in greater numbers in water with higher chl a concentration (suggesting areas of higher productivity). Areas with lower sea height and sea height anomaly were also important. These features suggest meso-scale cold-core eddy features, which together with the fronts at their edges have been highlighted in previous studies of seabird distribution (e.g. Schneider 1982, Hunt \& Schneider 1987, Skov \& Durinck 2000). Wind strength was negatively correlated with the numbers of shearwaters observed. This may have indicated that the shearwaters were most active at lower wind speeds, or alternatively, that they were more difficult to observe at high wind speeds.

The ocean characteristics highlighted in this paper are known to influence the distribution of other seabirds. Grey-headed albatross Thalassarche chrysostoma (Forster, 1785) from Marion Island concentrated at the edge of both warm and cold eddies associated with the Agulhas Current (Nel et al. 2001). Yellow-nosed albatross T. carteri (Rothschild, 1903) foraged in the Agulhas return current, concentrating in areas of increased chl a concentrations and sea height anomalies that indicated productive cyclonic eddies (Pinaud \& Weimerskirch 2005). Similar eddy structures are present in the Tasman Sea in the EAC and the Tasman Front (TF). The fronts at the edge of eddies have been shown to be highly productive areas with increased prey (Pinaud \& Weimerskirch 2005). While they are dynamic structures, and are therefore not going to remain in a place where shearwaters may return to each year, they are likely to be in approximately similar positions so that the shearwaters can move to a known region at least at larger scales. This will have the effect of reducing the area that may need to be visited to locate food.

\section{Predicting by-catch events}

Data collected by fisheries observers is likely to be the main source for observations of seabirds at sea in many situations, due to being relatively cheap to collect and the observers already being at sea. Studies of the distribution of seabirds using at-sea observations generally exclude counts from around commercial fishing vessels (Camphuysen et al. 2004) as this is thought to bias the results, yielding estimates of the distribution and abundance that are likely to be overestimated (Hyrenbach 2001, Arata \& Xavier 2003). While the data on seabird density may be artificially high if taken from fishing vessels, this bias should be present across all observations. This means that at reasonably large spatial scales it will remain representative of the relative abundance of birds across spatial locations.

The model was used to predict areas with the greatest number of encounters with fisheries in 3 years. By-catch of flesh-footed shearwaters is positively correlated with the numbers present around long-liners (Trebilco et al. 2010). While the model predicted the seabird distribution to be fairly consistent spatially between years, the area that was actually used by the fishery varied considerably. Thus in 2003-04 when greater effort was made by the fishery targeting yellowfin, there was a great deal of effort in areas where encounters were predicted to be greatest. Seabird bycatch rates were high in that period (Trebilco et al. 2010, Tuck \& Wilcox 2010). In 2006-07 when the fishery was largely targeting albacore, most effort was well to the north of that where encounters with shearwaters was greatest, and by-catch rates were relatively low (Trebilco et al. 2010, Tuck \& Wilcox 2010). In 1997-98 most effort was concentrated within the EAC close to the east coast of Australia and east of Mooloolaba. There was relatively little effort to the 
south-west of Lord Howe Island in the area of highest predicted encounters. This may suggest that mortality would have been low for that year, though no data exists on seabird by-catch.

Broadly, the model predicted that the shearwaters will be foraging in similar areas from year to year, with smaller differences due to spatio-temporal differences in conditions. The area with the highest predicted chance of encounters between fisheries and shearwaters to the south-west of Lord Howe Island was the area with the greatest observed mortality over the 1998 to 2004 period (Baker \& Wise 2005, Trebilco et al. 2010). The 3 years of fishing data had major shifts in the areas being used, depending on which species were being targeted. In recent years, fishing effort in the ETBF has shifted to targeting albacore tuna to the north of Lord Howe Island (Fig. 3f; Tuck \& Wilcox 2010). There has been a dramatic decrease in the estimated mortality of flesh-footed shearwaters over this time (G.B. Baker pers. comm.).

The use of area closure appears to be a viable means to reduce the mortality of seabirds that do not prove amenable to more standard methods of mitigation. This can be seen as analogous to the method of using Marine Protected Areas (MPAs) for the protection of vulnerable fish species (Pauly et al. 2002, Hilborn et al. 2004). However, where generally fisheries MPA's are used to close specific areas, this has been argued to be of limited use in the case of highly mobile species (Hilborn et al. 2004). Area closures were recently adopted to protect sea turtles in Hawaii in the long-line fishery for broadbill swordfish (Curtis \& Hicks 2000). However this involved closing a very large area to fishing. The need for MPAs to be extremely large to accommodate mobile species has been mentioned previously (Hyrenbach et al. 2000). Closure of such areas is likely to significantly impact fishing economies (Curtis \& Hicks 2000). Having greater knowledge of the requirements of more mobile species (such as their relationships with oceanographic features) may make it possible to develop temporary or more restricted area closures (Louzao et al. 2009, Žydelis et al. 2011). Fishers may be willing to voluntarily forgo fishing in areas that are likely to have high by-catch if these areas can regularly be identified, are not the only areas they have available, and especially if voluntary avoidance reduces the likelihood of a full fishery closure. Closures of this nature could be monitored by Vessel Monitoring System (VMS), which is present in the ETBF and widely used in many fisheries. Short-term closures of this nature would be advantageous to fishermen by only requiring them to avoid areas for periods of days or weeks.
This study shows that a model with relatively simple inputs can greatly assist in our understanding of the distribution of seabirds, their potential foraging areas and, importantly, where threats such as fisheries interactions are most likely to occur. This model was developed with the aim of identifying areas where most interactions occurred, and hence where mortalities would be likely to be highest, with the view of using it as a dynamic, rather than static, approach to short-term area closures. These areas could be identified from the use of a model such as this one, in particular using the explanatory variables (oceanographic and environmental) within the model that are variable over shorter periods. Further improvement could be made by identifying the rates of change of the explanatory variables. While the variables on seasonal timing and position never change, the oceanographic variables such as ocean colour and sea height potentially change over periods of days and weeks, and environmental variables such as wind speed and direction change over periods of hours or days. The more rapidly variables change, the less useful they are for making forward predictions due to their being out of date more rapidly. The shorter the time-span over which the variable operates, whilst giving the advantage of smaller area closures, also means the area closures need to be updated more frequently. There will then need to be a method for this updating to occur.

\section{CONCLUSIONS}

Data collected by fisheries observers were used to model areas of interactions between seabirds and fisheries in the ETBF. The model developed highlighted areas to the south-west of Lord Howe Island as having increased interactions. In one of 3 years when the fishery concentrated in this area, there were high observed seabird mortalities, while in another year when it concentrated in other areas, there were low observed mortalities. This work shows the potential of area closures for the reduction of seabird mortality for species that prove intractable to standard seabird mitigation techniques.

Acknowledgements. Fisheries data was supplied by the Australian Fisheries Management Authority (AFMA), and remote sensing data was supplied by the Commonwealth Scientific and Industrial Research Organisation (CSIRO). NCEP reanalysis data provided by the NOAA-CIRES Climate Diagnostics Center, Boulder, Colorado, from their web site at www.cdc.noaa.gov/. This study was supported by a joint CSIRO-UTas QMS scholarship. 


\section{LITERATURE CITED}

AFMA (2008) Australian Tuna and Billfish Fisheries. Bycatch and discarding workplan. November 1, 2008 to October 31, 2010. Australian Fisheries Management Authority. Available at www.environment.gov.au/coasts/ fisheries/commonwealth/eastern-tuna-billfish/pubs/att7workplan.pdf (accessed 21 September 2011)

AFMA (2011) Eastern Tuna and Billfish Fishery. At a glance. Australian Fisheries Management Authority. Available at www.afma.gov.au/managing-our-fisheries/ fisheries-a-to-z-index/eastern-tuna-and-billfish-fishery/ at-a-glance/ (accessed 8 August 2011)

Anderson ORJ, Small CJ, Croxall JP, Dunn EK, Sullivan BJ, Yates O, Black A (2011) Global seabird bycatch in longline fisheries. Endanger Species Res 14:91-106

Arata J, Xavier JC (2003) The diet of black-browed albatrosses at the Diego Ramirez Islands, Chile. Polar Biol 26: 638-647

> Baker GB, Wise BS (2005) The impact of pelagic longline fishing on the flesh-footed shearwater Puffinus carneipes in Eastern Australia. Biol Conserv 126:306-316

Barraquand F, Benhamou S (2008) Animal movements in heterogeneous landscapes: identifying profitable places and homogenous movement bouts. Ecology 89: 3336-3348

Bartle JA (1991) Incidental capture of seabirds in the New Zealand subantarctic squid trawl fishery, 1990. Bird Conserv Int 1:351-359

Bestley S, Patterson TA, Hindell MA, Gunn JS (2008) Feeding ecology of wild migratory tunas revealed by archival tag records of visceral warming. J Anim Ecol 77: 1223-1233

Brothers N (1991) Albatross mortality and associated bait loss in the Japanese longline fishery in the Southern Ocean. Biol Conserv 55:255-268

Brothers NP, Cooper J, Lokkeborg S (1999) The incidental catch of seabirds by longline fisheries: worldwide review and technical guidelines. FAO Fisheries Circular No 937 , Food and Agriculture Organisation of the United Nations, Rome

Buchholz A, Hollander N, Sauerbrei W (2007) On properties of predictors derived with a two-step bootstrap model averaging approach: a simulation study in the linear regression model. Comput Stat Data Anal doi:10.1016/ j.csda.2007.10.007

Buckland ST, Burnham KP, Augustin NH (1997) Model selection: an integral part of inference. Biometrics 53: 603-618

Camphuysen CJ, Fox AD, Leopold MF, Petersen IK (2004) Towards standardised seabirds at sea census techniques in connection with environmental impact assessments for offshore wind farms in the UK: a comparison of ship and aerial sampling methods for marine birds, and their applicability to offshore wind farm assessments. Royal Netherlands Institute for Sea Research, Texel, available at www.jncc.gov.uk/pdf/Camphuysenetal2004_ COWRIEmethods.PDF

Cressie NAC (1993) Statistics for spatial data. John Wiley and Sons, New York, NY

> Curtis R, Hicks RL (2000) The cost of sea turtle preservation: the case of Hawaii's pelagic longliners. Am J Agric Econ 82:1191-1197

Hilborn R, Stokes K, Maguire JJ, Smith T and others (2004) When can marine reserves improve fisheries manage- ment? Ocean Coast Manag 47:197-205

Hobday AJ, Hartmann K, Hartog J, Bestley S (2006) SDODE: spatial dynamics ocean data explorer. User Guide. CSIRO Marine and Atmospheric Research, Hobart

Hunt GL, Schneider DC (1987) Scale dependent processes in the physical and biological environment of marine birds. In: Croxall J (ed) Seabirds: feeding biology and role in marine ecosystems. Cambridge University Press, Cambridge, $\mathrm{p}$ 7-41

Hyrenbach KD (2001) Albatross response to survey vessels: implications for studies of the distribution, abundance, and prey consumption of seabird populations. Mar Ecol Prog Ser 212:283-293

Hyrenbach D, Forney KA, Dayton PK (2000) Marine protected areas and ocean basin management. Aquat Conserv 10:437-458

- Kacelnik A (1984) Central place foraging in starlings (Sturnus vulgaris). I. Patch residence time. J Anim Ecol 53: 283-299

> Lambert D (1992) Zero-inflated Poisson regression, with an application to defects in manufacturing. Technometrics 34:1-14

> Louzao M, Becares J, Rodriguez B, Hyrenbach KD, Ruiz A, Arcos JM (2009) Combining vessel-based surveys and tracking data to identify key marine areas for seabirds. Mar Ecol Prog Ser 391:183-197

Marchant S, Higgins PJ (eds) (1990) Handbook of Australian, New Zealand and Antarctic birds: ratites to ducks. Vol 1. Oxford University Press, Melbourne

- Minami M, Lennert-Cody CE, Gao W, Roman-Verdesoto M (2007) Modeling shark bycatch: the zero-inflated negative binomial regression model with smoothing. Fish Res 84:210-221

Nel DC, Lutjeharms JRE, Pakhomov EA, Anorge IJ, Ryan PG, Klages NTW (2001) Exploitation of mesoscale oceanographic features by grey-headed albatross Thalassarche chrysostoma in the southern Indian Ocean. Mar Ecol Prog Ser 217:15-26

Nel DC, Ryan PG, Watkins BP (2002) Seabird mortality in the Patagonian toothfish longline fishery around the Prince Edward Islands. Antarct Sci 14:151-161

Orians GH, Pearson NE (1979) On the theory of central place foraging. In: Horn DJ, Mitchell RD, Stairs GR (eds) Analysis of ecological systems. Ohio University Press, Columbus, OH, p 154-177

> Pauly D, Christenson V, Guenette S, Pitcher TJ and others (2002) Towards sustainability in world fisheries. Nature 418:689-695

Pennington M (1996) Estimating the mean and variance from highly skewed marine data. Fish Bull 94:498-505

> Phillips RA, Silk JRD, Croxall JP, Afanasyev V (2006) Yearround distribution of white-chinned petrels from South Georgia: relationships with oceanography and fisheries. Biol Conserv 129:336-347

> Pinaud D, Weimerskirch H (2005) Scale-dependent habitat use in a long-ranging central place predator. J Anim Ecol 74:852-863

> Priddel D, Carlile N, Fullager P, Hutton I, O'Neill L (2006) Decline in the distribution and abundance of flesh-footed shearwaters (Puffinus carneipes) on Lord Howe Island, Australia. Biol Conserv 128:412-424

R Development Core Team (2007) The R project for statistical computing, available at www.r-project.org/

Reid TA, Hindell MA (2000) Coarse-scale relationships between seabirds and zooplankton off south-eastern 
Tasmania. Mar Freshw Res 51:789-798

Reid TA, Hindell MA, Eades DW, Newman M (2002) Seabird atlas of south-eastern Australian waters. Birds Australia Monograph 4. Birds Australia, Melbourne

Ross GJW, Weaver K, Greig JC (eds) (1996) Status of Australian seabirds: proceedings of the National Seabird Workshop, 1-2 November 1993. Biodiversity Group, Environment Australia, Canberra

Schneider DC (1982) Fronts and seabird aggregations in the southeastern Bering Sea. Mar Ecol Prog Ser 10:101-103

Shaffer SA, Tremblay Y, Weimerskirch H, Scott D and others (2006) Migratory shearwaters integrate oceanic resources across the Pacific Ocean in an endless summer. Proc Natl Acad Sci USA 103:12799-12802

Skov H, Durinck J (2000) Seabird distribution in relation to hydrography in the Skagerrak. Cont Shelf Res 20: 169-187

Spear LB, Ainley DG, Hardesty BD, Howell SNG, Webb SW (2004) Reducing biases affecting at-sea surveys of seabirds: use of multiple observer teams. Mar Ornithol 32:147-157

Stanton BR (1981) An oceanographic survey of the Tasman Front. N Z J Mar Freshw Res 15:289-297

Stramma L, Peterson RG, Tomczak M (1995) The South Pacific Current. J Phys Oceanogr 25:77-91

Sullivan BJ, Reid TA, Bugoni L (2006a) Seabird mortality on factory trawlers in the Falkland Islands and beyond. Biol Conserv 131:495-504

Editorial responsibility: Hans Heinrich Janssen, Oldendorf/Luhe, Germany
Sullivan BJ, Brickle P, Reid TA, Bone DG, Middleton DAJ (2006b) Mitigation of seabird mortality on factory trawlers: trials of three devices to reduce warp cable strikes. Polar Biol 29:745-753

Thalmann SJ, Baker GB, Hindell M, Tuck GN (2009) Longline fisheries and foraging distribution of flesh-footed shearwaters in Eastern Australia. J Wildl Manag 73: 399-406

Trebilco R, Gales R, Lawrence E, Alderman R, Robertson G, Baker GB (2010). Characterising seabird bycatch in the Eastern Australian Tuna and Billfish pelagic longline fishery in relation to temporal, spatial and biological influences. Aquatic Conserv: Mar Freshw Ecosyst doi: 10.1002/aqc.1115

Tuck GN, Wilcox C (2010) Assessing the impacts of fishing on the Lord Howe Island population of the flesh-footed shearwater. AFMA Project R2003/1404. Australian Fisheries Management Authority and CSIRO Marine and Atmospheric Research, Hobart

Zeileis A, Kleiber C, Jackman S (2007) Regression models for count data in R. Research Report Series 53. Department of Statistics and Mathematics, Wirtschaftsuniversitat Wein, available at http://epub.wu-wien.ac.at/dyn/ virlib/wp/eng/mediate/epub-wu-01_bca.pdf?ID=epubwu-01_bca

Žydelis R, Lewison RL, Shaffer SA, Moore JE and others (2011) Dynamic habitat models: using telemetry data to project fisheries bycatch. Proc R Soc B 278:3191-3200

Submitted: April 13, 2011; Accepted: October 17, 2011

Proofs received from author(s): January 13, 2012 